economic reality of globalised sport (the business of sports event organisation, which had become highly competitive due to the inflation in television rights following the appearance of subscription television networks) was growing, and public incomprehension and distrust of professional sports leagues and private event organisers remains strong, especially in Europe. This moral crisis has led to a degree of disaffection with sport that has been strengthened by revelations of corruption at the highest levels of the IOC and international federations, and by sport's seeming inability to effectively combat doping and match fixing. The Festina affair in 1998 destroyed the credibility of cycling, while the Salt Lake City scandal in 1999 had a similar impact on the IOC-new means of communication such as the Internet have not only enabled major sports events to grow massively around the world, they have also made consumers less naïve. The crisis in sport's governance game to a head in 2015, when an investigation led by the US Department of Justice found enough evidence of corruption within FIFA, the world's largest sport federation, to topple many of the federation's top executives, including its once all-powerful and untouchable president, Sepp Blatter. A few months after FIFAgate, allegations that members of the IAAF solicited bribes in order to cover up widespread doping by Russian athletes resulted in the fall from grace of another of sport's most powerful executives, the IAAF's Senegalese president, Lamine Diack. As the first African to preside a major international sports federation, Diack was the pride of African sport. Nevertheless, the Russian doping cover up, in which Diack's son was also implicated, brought an end to Diack's 15-year reign.

Sport's governing bodies have attempted in vain to stamp out misconduct and thereby avoid policing actions by the European Union and individual countries, especially the United States, whose justice department has been particularly active in pursuing cheats and mafias. However, regulatory bodies created within the world of sport, such as the World Anti-Doping Agency (WADA) and the Court of Arbitration for Sport (CAS), have shown their limits, and there is little evidence as yet that sport will be able to put its own house in order. Consequently, we are in the heart of the storm and a new form of governance is being developed under our very eyes.

\section{Hein Verbruggen: Bringing a Corporate Mentality to the Governance of Sport}

\author{
Josephine Clausen and Emmanuel Bayle
}

He's a true politician, patient if necessary, but also almost brutal if necessary [free translation from French]. (Jean-Marie Leblanc, former Tour de France Director) ${ }^{1}$

There are very good and professional people in the international sport federations. But if you look at the structure and organisation of them it simply cannot be good. (Hein Verbruggen, November 2014)

The link between international sport federations (IFs) and business is still a recent phenomenon, a tandem of mutual benefit that has evolved over the last three decades. Before this, by their very nature, IFs with their social mission and business as an economic activity constituted two completely distinct worlds. The former promoting, above all,

J. Clausen - E. Bayle (区)

Institute of Sports Studies (ISSUL), University of Lausanne,

Lausanne, Switzerland

e-mail: Emmanuel.bayle@unil.ch

J. Clausen

e-mail: Josephine.Clausen@unil.ch

(9) The Author(s) 2018

E. Bayle and P. Clastres (eds.), Global Sport Leaders, 
pastimes and a forum for social encounters; the latter being profitand outcome-oriented, optimised by strategic planning, performance management and quality controls. With increasing public interest in sport spectating (Robinson 2003) and the explosion of broadcasting rights in the 1990 s, the worlds of sport and business began to converge under the doctrine of performance and effectiveness (Barbusse 2002). Through the merging of the traditionally diverging logics of non-profit sport organisations and business corporations, IFs have become hybrid constructs (Bayle et al. 2011). These transformations have introduced a new group of actors: sport managers. For these actors, the business world, with its rules, constraints and expectations, has become the point of reference (Barbusse 2002). For transformations to take place, it is indispensable to have people who envisage, introduce and lead change (Amis et al. 2004). Hein Verbruggen was such a person.

A businessman at heart and by conviction, Hein Verbruggen brought new perspectives into the world of cycling and international sport. His leadership, pragmatic marketing and management approach, which have profoundly shaped international cycling and the Union Cycliste Internationale (UCI) as its international governing body, were not without controversy. Some describe Hein Verbruggen as a person with "opportunistic behaviour and decisions driven by money" (former president of a national cycling federation) having an "oversized ego" (former UCI staff member), and allegations from riders (e.g. Floyd Landis, Paul Kimmage), the media (e.g. BBC) and a report commissioned by the UCI publicly accused Hein Verbruggen of wrongdoings.

A chapter about Hein Verbruggen could tell many different stories: the story of the visionary UCI President; the story of an IOC member and President of SportAccord; or the story of Hein Verbruggen as a highly controversial figure in cycling who was confronted by allegations of complicity and laxity in the fight against doping. Rather than sketching a complete picture of Hein Verbruggen as a person, this chapter seeks to outline his main influences on the international sporting world through interviews with him and by impartially gathering impressions from former employees, contemporary witnesses and relevant documents (e.g. newspaper articles, reports). In particular it focuses on two developments on which Hein Verbruggen had a significant influence: the professionalisation of structures and processes at the UCI by applying corporate management knowledge and practices; and the transformation of GAISF (General Association of International Sports Federations, renamed SportAccord between March 2009 and April 2017) to become a service provider to IFs and a multi-sport games organiser. This chapter is the story of Hein Verbruggen's strong belief in, and reliance on, corporate management principles. It is the story of how he introduced these principles to sport, adapted them to its reality and how these principles have left a legacy in the world of international sport. It is also the story of the ambivalent spirit of IFs since the 1990s: on the one hand, there are all-powerful presidents, a lack of transparency, doping and corruption scandals and waning credibility; on the other hand, major sport events bring together thousands of people from all over the world and event revenues allow IFs to finance development projects.

The chapter will focus on Hein Verbruggen the marketing expert and his entry into the world of sports, his managerial vision as a businessman and its implementation at the UCI and his reform of GAISF to become a service provider to IFs and a multi-sport games organiser. As a person who strongly divides opinion, a short overview of some of the allegations against him is also given. The chapter concludes with a summary of Hein Verbruggen's main achievements. Information is based on ten interviews-three of which were with Hein Verbruggen and seven with former employees and contemporary witnesses-as well as newspaper articles and a data analysis of IOC, UCI and GAISF documents.

\section{The Marketing Expert Who Became a Key Leader in International Sport}

Born on June 21, 1941 in Helmond, a city in the province of North Brabant (Netherlands), Hein Verbruggen grew up in a region where cycling and enthusiasm for cycling have a long tradition. However, he had very little to do with cycling in his younger years, besides perhaps occasions on which his father took him to watch a local cycling race. Education was highly valued in the Verbruggen family. Hein Verbruggen 
completed his studies at the Nijenrode Business School in 1964 and started his first job as Regional Sales Manager for Carnation Belgium the same year, where he "received a very good training in sales" (HV, April 2015). Following this first professional experience at Carnation (1964-

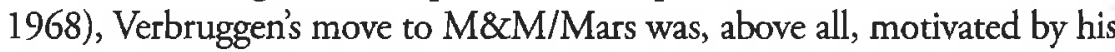
desire to enter the marketing sector. He was hired as a Product Manager (1969), a job that had a significant impact on his later philosophy and vision. From the age of 28 , his understanding of business, marketing, management and strategic planning was largely formed during his years with $\mathrm{M} \& \mathrm{M} / \mathrm{Mars}$, a company he described as "one of the best companies in the world" (HV, November 2014). Many of the skills he acquired during this time served him well when occupying pivotal positions in the world of sports. His strong identification with the Mars principles of "quality responsibility, ethics and efficiency" (HV, April 2015) became his point of reference. But how did Hein Verbruggen get into the world of cycling, a world that, at that time, was still the reserve of individuals closely involved with cycling and/or who had an emotional attachment to the sport?

\section{The Mars-Flandria Sponsorship Deal}

At first sight, Hein Verbruggen's entry into the world of sport could be considered as a mere coincidence: looking for new possibilities to advertise $\mathrm{M} \& \mathrm{M} / \mathrm{Mars}$ ' products in a fast-growing international food market, the young sales manager convinced his employer to sponsor a cycling team, proving a subtle instinct for business, strategic alliances and marketing opportunities. Firstly, sport creates emotional links and can improve the image of a product by simple association with the emotional experience of the sport, an event, athletes, etc. Secondly, in the 1970s and 1980s, sport was discovered to be an ideal platform to promote products. It became a new advertising tool, marking the beginnings of sport sponsorship. And thirdly, the particular circumstances of the law in Belgium made sport events and teams/athletes ideal partners for the advertising industry: in the 1970s, Belgium was one of few countries (along with Scandinavia) where commercial advertising was banned on radio and television. Verbruggen opened a new door for M\&M/Mars to promote their products by signing a two-year sponsorship contract with a Belgium cycling team in 1970 (Mars-Flandria). Sponsorship from outside the world of cycling was still relatively new at this time. Until the mid-1950s, sponsorship and the organisation of cycle races were strictly limited to cycling manufacturers and newspapers. However, with the increasing popularity of cycling events and the professionalisation of athletes, bicycle manufacturers were unable to finance the sport alone. In 1954, Italian cyclist Fiorenzo Magni became an emblem of this change in cycling: his bike company, Ganna, was unable to continue financing his team. Magni turned to the German cosmetic company Nivea and signed a contract with them as team title sponsor. For the first time in cycling history, a brand outside the world of cycling became the sponsor of a cycling team. ${ }^{2}$

In 1975, persuaded by one of the Mars-Flandria riders, Hein Verbruggen became actively involved in cycling as a member of the professional cycling committee of the Royal Dutch Cycling Union (KNWU). From this time on, he began to shape the sport from the inside. Just four years later, in 1979, he became a board member of the Fédération Internationale de Cyclisme Professionnel (FICP), then Vice-President of FICP in 1982 and President in 1984. In 1991 he was elected President of the UCI. Verbruggen's career path illustrates how rapidly he grew into the role of a major actor in international cycling and in sport in general. This chapter studies the following contributions of Verbruggen: his pragmatic management approach triggering the professionalisation of the UCI and the creation of a support base for all IFs in the Olympic movement through the services provided by GAISF.

\section{A Pragmatic Management Approach: The Example of the UCI}

If you look around in the world, for me the best management system you can find is in the multi-nationals. (HV, November 2014)

Hein Verbruggen was at the head of the UCI for 14 years. When elected President in 1991, the Geneva-based UCI headquarters (transferred from Paris to Geneva in 1969) consisted of two people: a Polish Secretary General aged 79 and his assistant. When Hein Verbruggen left 
the UCI in 2005, the federation employed 55 staff members, had its headquarters in a new velodrome in Aigle and enjoyed a stable financial and patrimonial situation: "I took up a bankrupt federation and when $I$ left there were a cycling centre, all paid for, and 14 millions [CHF] of reserves," (HV, November 2014). Hein Verbruggen has shaped international cycling in many ways. The focus will, however, be limited to two particular achievements that reflect his management style, his fine sense of policy and his relentless pursuit of improved organisational performance. The first of these achievements was the dissolution of the FICP and the Fédération Internationale Amateur de Cyclisme (FIAC), finally conferring the UCI with the role of the sole international representative for the governance, promotion and development of cycling worldwide. The second achievement was the creation of the UCI ProTour, now known as the UCI WorldTour.

\section{Reversing the Effects of the Amateur Code}

As a member of the Dutch national cycling federation since 1975, Hein Verbruggen first participated in a FICP/FIAC Congress in 1978 (Munich). He immediately presented himself as candidate for one of three vacant FICP posts and was elected at the following FICP Congress held in Maastricht on 20 August 1979. His election allowed him to attend the UCI Congress (Geneva, 30 November 1979). When Verbruggen was elected to the board of the Luxembourg-based FICP in 1979, there was still a long way to go before the FICP and the FIAC would be dissolved. Both federations were formally under the direction of the UCI but in reality the UCI had no influence. A closer look at the historical evolution of the Olympic Games is required to understand why the UCI, as the international governing body of cycling, was flanked by two additional international federations-FICP and FIACof which only the FIAC was recognised by the IOC.

The 1964 amateur code excluded from the Olympic Games those athletes: who have participated for money, or who have converted prizes into money or, without permission of the National Federation within the Rules of the International Federation concerned, have received prizes which can be converted intolue, and those who have received presents which can be converted into money or other material advantages. ${ }^{3}$

In 1965, the IOC under the presidency of Avery Brundage obliged both the UCI and FIFA to split into amateur and professional branches, a utes of the 63rd other IFs had already undertaken. As stated in the minnate the sports whose fedentions IOC (1965), "the I.O.C. decided to elimiat the same time". As a result govern professional sport and amateur sport tion FIAC and the amateur association FIAC and the professional association FICP. It was not until 1981 accepted ry the accepted by the IOC Congress (Baden-Baden, Germany). By 1984, the Olympic Games were effectively open to professional athletes.

However, having conceded to the pressure of the IOC, the UCI was caught in the crossfire of two rival federations for the next 27 years. The UCI Management Committee comprised 50\% FIAC members and $50 \%$ FICP members. The two-bloc arrangement was symbolic of the FLAC the Communist countries from the Eastern bloc dominated the FLAC, the FICP was characterised by a capitalist mindset. "Everything they [FIAC] said, we [FICP] said no. And everything we said, they said no," (HV, November 2014). In this 50/50 deadlock, the UCI President could steer a vote in one or other direction by his casting vote. It also meant that decisions supported by the majority were rare. This situation virtually paralysed the development of the UCI for 27 years. And it was only with the UCI's official recognition by the IOC in 1993 that professional cyclists could finally participate again in the Olympic Games, the first being the 1996 Games in Atlanta. Verbruggen's efforts were key to the reintegration of the UCI into the Olympic Movement and the concentration of decision-making powers within the UCI as the sole governing body.

How did the situation unfold? In 1984, the FICP sought a new president to complete the mandate of the deceased Josy Esch. Two candidates stood for election: Hein Verbruggen and Germain Simon (France). Verbruggen was elected FICP President on 28 November 1984. 
Six years later (July 1990), the UCI found itself without a president after the death of Louis Puig (Spain). Verbruggen stood for the post and was elected on 29 November 1991 at the UCI Congress in Berlin. With the division into three international federations (FIAC, FICP, UCI) of which only the FIAC was recognised by the IOC, the UCI was clearly not in a position to promote the sport it represented as the international governing body. The dissolution of the FIAC and the FICP therefore became Hein Verbruggen's first objective as the newly elected UCI President.

Two events facilitated the unification. On the one hand, the separation of amateurs and professionals became superfluous from a sporting point of view due to the abolition of the amateur code (1981). On the other hand, the end of the Cold War and the demise of the Union of Soviet Socialist Republics (USSR) in 1989 simplified the destruction of the "iron curtain" in cycling. The path was clear for the rapprochement of the FIAC and FICP blocs. With the support of Juan Antonio Samaranch (IOC President from 1980 to 2001), Hein Verbruggen succeeded in his first mission: in 1992, the decision to dissolve the FIAC and FICP was passed by the UCI Congress (Orlando, USA). The decision was finalised in August 1993, leading to the reintegration of the UCI into the Olympic Movement in the same year. Instead of FIAC and FICP, two new councils were created-the Amateur and Professional Councils - but these only existed for a short time. During the 1996 UCI Congress (Lugano, 11 August), the two councils were abolished. The Professional Council was subsequently replaced by two commissions: the Road Elite Commission and the Road Commission. Four years later, in order to better respond to the growing popularity and success of professional cycling, the UCI announced the creation of the Professional Cycling Council (PCC) at the 2000 UCI Congress (Sint Michielsgestel, 28 January). This Council still exists today and is, among other things, responsible for carrying out the technical and administrative organisation of the UCI WorldTour, drawing up the WorldTour calendar and drafting regulations specific to UCI WorldTour Teams. The events leading to the creation of the PCC demonstrate the UCI's strong focus on road cycling.

\section{The Creation of the ProTour: A Means to Control the International Cycling Calendar}

Cycling lives on the myths of seemingly insurmountable challenges such as the first cycling race in 1891, from Paris to Brest and back over a total of $1300 \mathrm{~km}$, mostly on rough cobbled roads. Since then, and because of its potential to attract and fascinate people, cycling has has always been organised in function pressure groups: "Historically, sport in general ben organised in function of something else. This makes sport in general very vulnerable, and cycling in particular as cycling teams have no political backing and very little regional embedding" (HV, May 2015). The creation of the Tour de France is a perfect example of the instrumentalisation of cycling by press groups:

\section{The creation of the Tour de France and its success}

At the end of the 19th century, Le Vélo was the only daily sports magazine in France. Its Chief Editor, Pierre Giffard, supported Alfred Dreyfus industries. Nevertheless, the extreme discontent of the cycling and ca ity through advertising in the cycling and car industries had gained visibility through advertising in the magazine. In 1900, when the industrialists created their own daily sports magazine, L'Auto-Vélo, printed on yellow the rights for "vélo". L'Auto-Veut naming rights. As Le Vélo had reserved years later and velo", L'Auto-Vélo finally had to accept legal defeat three to the prospect and rename its magazine L'Auto. In the same year, in response to the prospect of losing considerable marketing opportunities, L'Auto launched a new strategy to increase its readership: organising the biggest de France (1903) seen-the Tour de France. The success of the first Tour de France (1903) afforded L'Auto a considerable advantage over its compaper upon which L'Auto was printed beca the following year. The yellow Tour de France leader's jersey.

Today, the mythical Tour de France is organised by ASO (Amaury Sport
Organisation). The Tour not nificant revenues. Tour not only has a long tradition, it also generates sigmaticant revenues. Tour de France net earnings in 2014 totalled approximately EUR 35 million (Aubel 2015), In 2013, 12 million spectators lined prize money was distributed, Tour de France, a total of EUR 2.2 million organisation of the event, 35,000 beds were booked by the organisation douring the Tour's three weeks, 1700 journalists were accredited and the Tour was broadcast to 195 countries, representing a total of 3.5 billion 
spectators worldwide. ${ }^{6}$ It is beyond doubt that an organisation like ASO does not need the UCI to make its economic model work. On the contrary, the UCI has often been an unwanted presence, imposing rules on an event that was created just three years after the UCI itself (1900), an event that has given rise to myths and stories of glory and defeat, and that has an economic impact like no other cycle race in the world. So far, neither Hein Verbruggen nor his successors have managed to control ASO as much as they would have liked. In 2014, 56 out of 154 race days on the WorldTour calendar were organised by ASO (Aubel 2015), giving the organiser considerable visibility and power.

In the years following the dissolution of the FICP and the FIAC, Hein Verbruggen concentrated his efforts on strengthening the UCI's influence on cycling events which, up until then, had been under the control of private commercial organisers, professional teams, broadcasters, sponsors, etc. This lack of control not only weakened the UCI's decision-making role, but also its financial capacities. Verbruggen was convinced that an IF has to control its international event calendar in order to govern its sport. During his time as a member of the FICP, he recognised the overwhelming power of some race organisers, notably the "Sociéte du Tour de France" (now known as ASO), the organiser of the Tour de France. The international cycling calendar in this era was literally in the hands of Félix Lévitan, Director of the Tour de France from 1962-1987: "ASO, or rather the Sport Director Felix Lévitan, took the decisions, the UCI merely approved them without opposition, reducing its own rights and power to an all-time low" (HV, November 2014).

Very quickly, Verbruggen realised that race owners were rather opposed to his vision for developing cycling. "The cycling calendar was to 70\% France, Spain, Italy and Belgium. And these federations didn't want to change. Every new race that came in was a big fight," (HV, November 2014). By introducing the ProTour as a UCI-owned circuit, he initiated a dynamic offensive against the all-powerful race organisers. Launched in 2005 during his last year as UCI President, the ProTour brought together the 18 strongest cycling teams at the most popular cycle races. Participation was no longer a question of good contacts with the organiser (as was previously common practice), but was instead based on a team ranking that had its origin in the French classification system. Baulking against the curtailment of their so far unlimited rights to choose teams and dates, a power battle arose between ASO and the UCI. This struggle continued even after the UCI ProTour had been launched in 2005, culminating in 2008 when ASO declared that it would quit the UCI calendar and organise its races independently. Having joined forces with other major organisers such as RCS (Giro d'Italia) and Unipublic (Vuelta a Espańa), ASO once again demonstrated its powerful position. In the end, the IOC had to intervene as a mediator to break the deadlock.

According to Verbruggen, the ProTour was pursuing a strategy of stabilising teams' financial situations by guaranteeing top-level participation. "The weak situation of teams was at the basis of the ProTour creation because teams are very vulnerable. We wanted to open new sources of revenues for the teams and bind sponsors via participation guarantees," (HV, April 2015). A process of the professionalisation and globalisation of cycle races and teams followed the creation of the ProTour (renamed WorldTour in 2011). Nowadays, race organisers have to follow a precise, very strict organisation guide, the implementation of which is controlled by professional UCI technical delegates. In addition, commissaires officiating at WorldTour races are specifically trained and WorldTeams, in order to receive their licence, have to prove their compliance with financial, ethical and sporting criteria defined by the UCI. Nevertheless, the economy of the system continues to be very fragile. Teams still rely entirely on their main sponsors, there is no redistribution of TV rights to the teams and athletes receive poor prize money compared to other top professional sports such as tennis (in 2015, number one player Novak Djokovic earned USD 21.6 million $^{7}$ in prize money alone) or golf (for the 2015 PGA $^{8}$ Championship, a total of USD 10 million was distributed to the top 21 players, the winner getting USD 1.8 million $^{9}$ ). Even for the UCI, the UCI WorldTour has not been very profitable, sometimes even returning a deficit: in 2013, high legal costs (CHF 718,000) and expenses for meetings (CHF 812,000) led to a WorldTour loss of CHF 96,000 (UCI Annual Report 2013). In 2014, the UCI WorldTour generated modest revenue of CHF 240,000 (UCI Annual Report 2014). Furthermore, cycling fans, potential sponsors and partners do not 
display much recognition of the "UCI WorldTour" brand whereas they are highly aware of the three biggest races of the WorldTour: the Tour de France, Giro d'Italia and Vuelta a España. ${ }^{10}$ The continuing reform of men's professional road cycling, with implementation planned for 2017-2019, in conjunction with the opposition of key stakeholders (e.g. race organisers, teams), emphasises the ongoing struggle between the UCI as the governing body of international cycling and stakeholders' individual needs and interests.

\section{Hein Verbruggen's Achievements as UCI President}

Hein Verbruggen's legacy to cycling and the UCI results from a wellthought out and well-conducted transformation of a traditional, volunteer-run and slightly dusty sport federation into a dynamic, professional and trendsetting federation. According to Verbruggen, one of his most important achievements is hardly mentioned: the reform of professional riders' working conditions by introducing social protection measures through an agreement between the UCI and economic partners (in particular social insurance guarantees and minimum salaries for road cyclists), signed in Lisbon on 12 October 2001. Before this, "riders were slaves, often paid in kind, not in cash. And the UCI Rulebook of a meagre seven to eight pages didn't contain any social protection for riders," (HV, April 2015). Today, the major challenges of guaranteeing viable working conditions for professional cyclists are still considerable as significant (budgetary) differences exist amongst teams and short-term sponsor agreements undeniably introduce uncertainty.

Another important change of paradigm under Hein Verbruggen was the creation of the ProTour (now known as the WorldTour). Even though the ProTour didn't entirely wrest the overwhelming power from race organisers such as ASO, it is today a solid component of the international road cycling calendar, bringing together the world's best road cycling teams and delighting millions of fans on the roadside and in front of the television. Critics claimed that the new series format embodies several disadvantages: teams are mainly racing for points (as these allow them to participate in major races) and riders have to accumulate a questionable amount of race days; the stars and figureheads have disappeared behind the "team" product while, at the same time, this product is extremely fragile and dependent on short-term sponsorship contracts. Twelve years after launching the ProTour (2005), race organisers and cycling teams are voicing significant dissent to the ongoing Reform of Men's Professional Cycling, which was supposed to be finalised by 2017. The criticisms come from several sides. WorldTour teams, for example, do not see their sporting needs reflected in the reform as race days are set to increase, contrary to an initial agreement.

Hein Verbruggen also promoted the commercialisation of the UCI World Championships and UCI World Cups. Cycling World Championships and World Cups now guarantee the UCI a major source of income, mainly through the sale of sponsorship and TV rights. Verbruggen marketed these rights at "a time where it was still rare to buy andlor sell TV rights" (former UCI staff member, March 2015). When contracting TV rights with the European Broadcasting Union (EBU) in the early nineties, the UCI immediately harvested some ten million Swiss francs. The contract with EBU included the commercialisation of all UCI World Championships with broadcasting guarantees, as well as penalties should the contract not be respected. A beneficial side effect of this TV deal was that it allowed the UCI to attract new international sponsors such as Tissot and Shimano, generating considerable additional income.

From an administrative perspective, staff numbers at the UCI gradually increased in line with the changes initiated by Verbruggen: three paid staff members in 1991, five in 1993, 20 in 1997 and 55 in 2005 (not including the staff of the World Cycling Centre). As a consequence of this increase, the UCI headquarters moved to its new home, the World Cycling Centre (WCC) in Aigle, Switzerland, inaugurated on 14 April 2002. Since this time, the WCC has been a driving force in the worldwide development of cycling (e.g. coaching and mechanics' courses, athletes' training).

As UCI President, Hein Verbruggen was a strong, forward-thinking leader who was calculating and tireless in the pursuit of his objectives. The evolution of the UCI, its professionalisation and the globalisation of cycling are in many ways the result of his vision and the implementation of this vision. However, Hein Verbruggen admitted, with a note 
of self-criticism, that his last term as UCI President lacked the motivation with which, hitherto, he had restructured and developed the UCI to become one of the biggest international sport federations: "I was fed up after 10 years and I had to stay another 4 years because Samaranch told me: 'You should not only build it [World Cycling Centre], but you should also run it.' And that was just 4 years too much. I didn't do the job at the level as I did before because my motivation was gone," (HV, November 2014).

Hein Verbruggen retired as UCI President in 2005, becoming a UCI Honorary President and co-opted member of the UCI Management Committee until 2008. The move to become a co-opted member was unusual for an honorary president as the latter role typically means quitting all executive functions. Some interpreted this situation as Verbruggen's desire to cling on to power. But it was also a tactical move undertaken in light of his ambitions regarding the IOC. Hein Verbruggen became an IOC member in 1996. To remain an IOC member and continue his work on the Coordination Commission for the Games of the XXIX Olympiad in Beijing in 2008 (2001-2008), to which he had been elected as Chairman in November 2001, he had to occupy an executive function within an IF. And the UCI Constitution offered a solution: according to Article 47, the UCI Management Committee, comprising 15 members at this time, could co-opt two additional members. Verbruggen was co-opted as a member of the UCI Management Committee in 2005, immediately after the election of his successor Pat McQuaid. He was also named UCI Vice-President of International Relations due to his numerous contacts with, and functions within, the IOC (President, Chairman and active member of various commissions), SportAccord (President from 2004-2013) and ASOIF, the Association of Summer Olympic International Federations (Vice-President from 2000-2003).

\section{GAISF/SportAccord}

Under the Presidency of Verbruggen the organisation has been able to move forward in a way that perhaps would not have been possible under any other President. (former SportAccord staff member, March 2013)
Though Hein Verbruggen relinquished his function as UCI President in 2005, it was clearly not to take a break or retire from international sports. In 2004, as GAISF Vice-President, he replaced Un-Yong Kim to become acting President. Kim was forced to resign over allegations of bribery and illegally acquiring public money intended for the World Taekwondo Federation (WTF) over which he presided. After three years as acting President, Verbruggen was officially elected GAISF President in 2007. Established in 1967, GAISF represents all IFs. However, its role as a link between IFs and the IOC and as a platform for exchange and the defence of IFs' common interests dates back to the 1920s.

\section{The collective representation of International Sport Federations}

Through the Conseil National des Sports (CNS), which brought together the leaders of the principal sport federations, France actively organised a counter-power to the $10 \mathrm{C}$ by promoting initiatives to organise collective world championships. In 1918, the CNS established the conditions for the creation of international groups, the equivalent of today's IFs. This project could have resulted in France assuming a hegemonic position within each If and in a Comite International des Sport (CIS). Aware of the threat to the Olympic movement, Pierre de Coubertin, with the help of some international leaders and IOC members, interrupted this attempt. As an alternative he established a Permanent Office of International Sports Federations in 1921, with headquarters in Paris (Grosset and Attali 2009). The office organised regular meetings between Olympic federations and the $10 C$, facilitating dialogue. However, non-Olympic federations were excluded. Having no representation vis-à-vis the $1 O C$ and no platform for exchange between federations to defend their common interests, 26 federations came together in Lausanne in 1967 to create the General Assembly of International Sports Federations, replacing the Permanent Office of International Sports Federations. The Assembly was rebranded the General Association of International Sports Federations (GAISF) in 1976 and became SportAccord in 2009. In April 2017, it was renamed the Global Association of International Sports federations, hence adopting its former acronym GAISF.

Hein Verbruggen became a leading figure in international sport through his position at GAISF. However, he came close to turning his back on GAISF in 2004: "GAISF didn't do anything. Nothing. We had two meetings per year that never lasted longer than 59 minutes. I was wondering what I was doing there?' (HV, November 2014). The inactivity of 


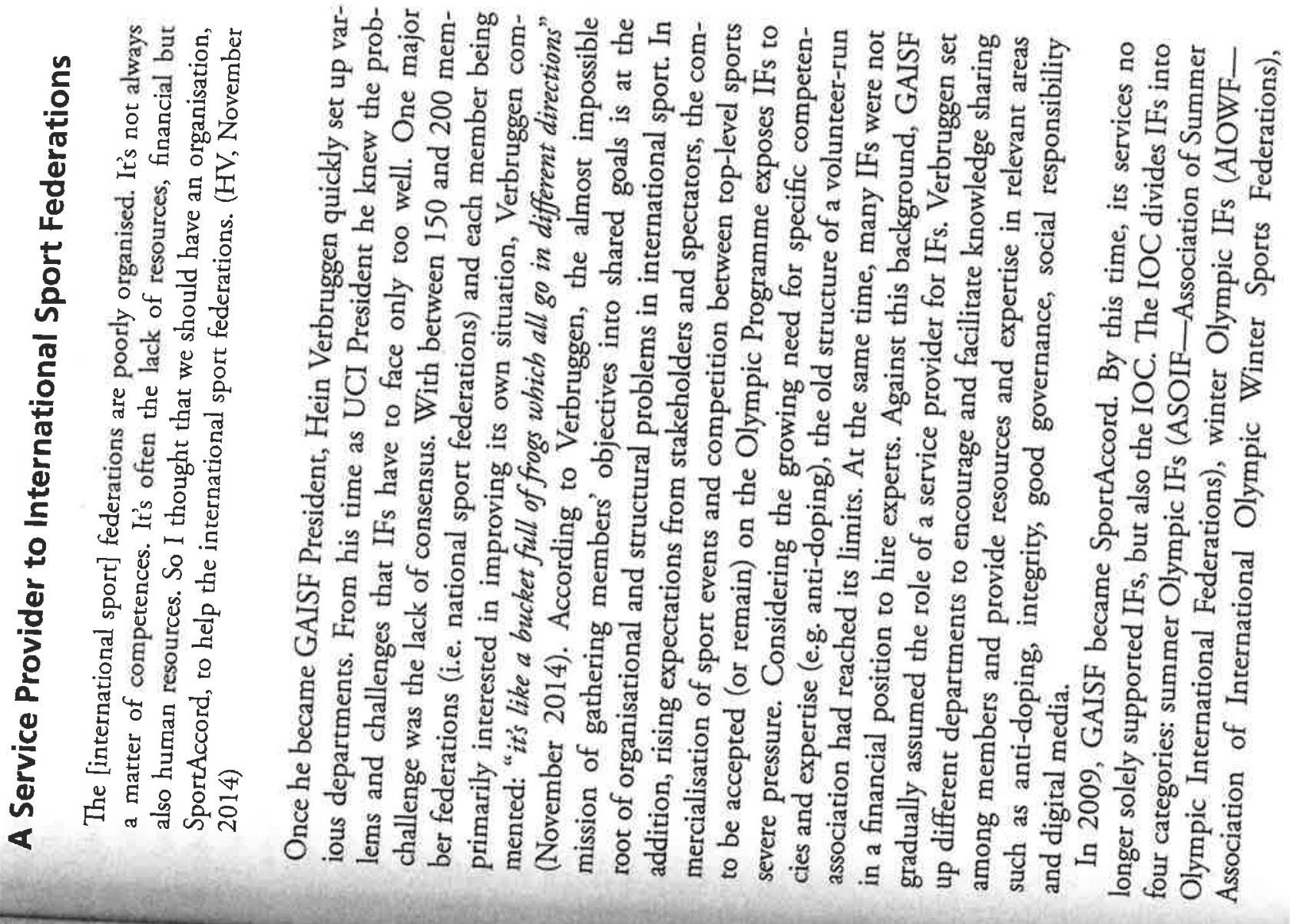

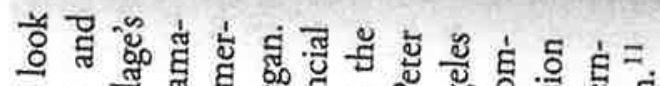

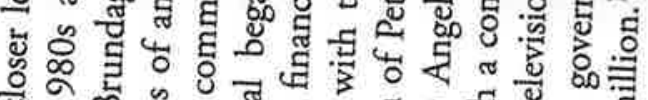
ป

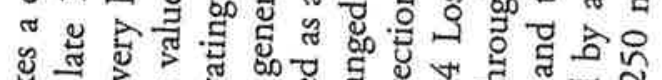

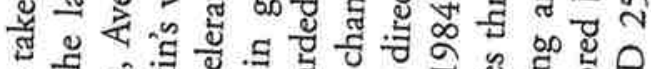
ป $\Rightarrow$. त्रूี

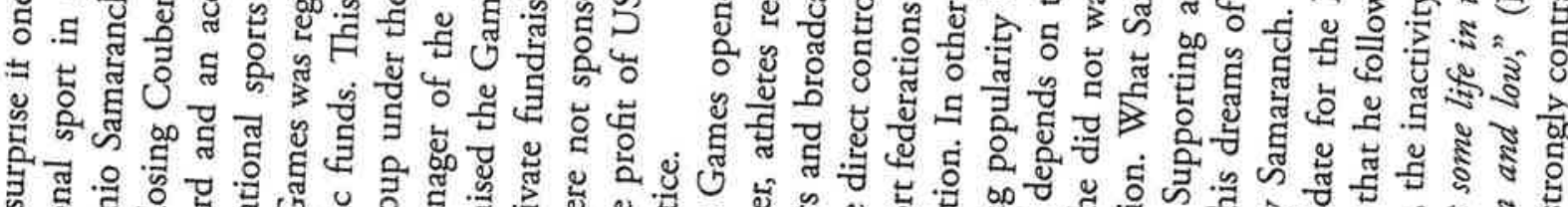

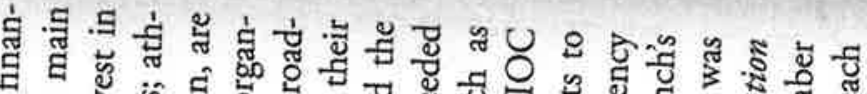

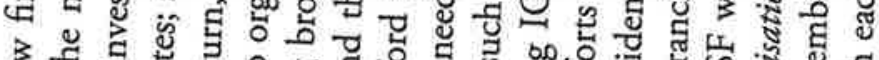

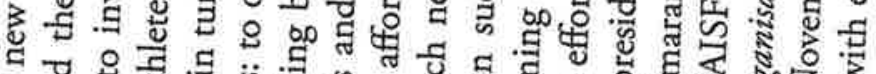

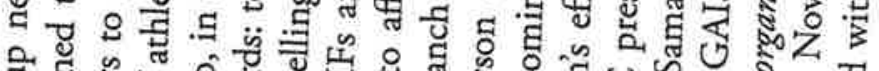

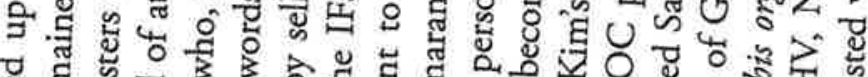

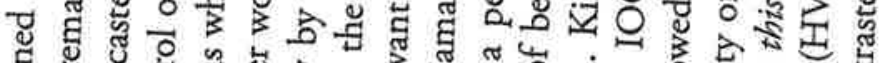
ปั

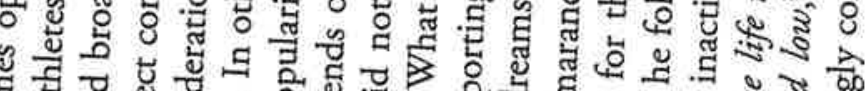

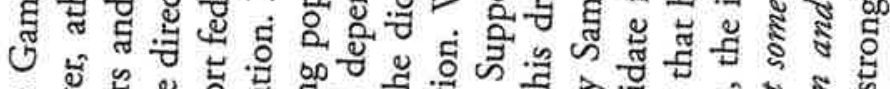

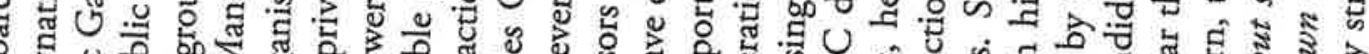

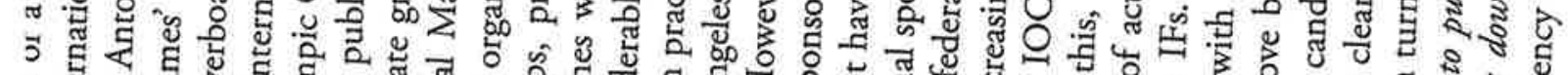

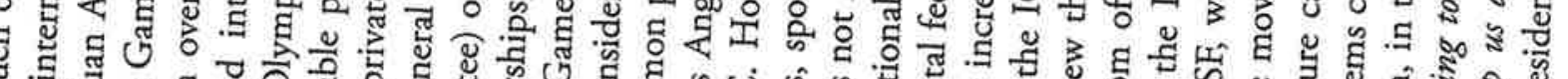
u. \& 马०

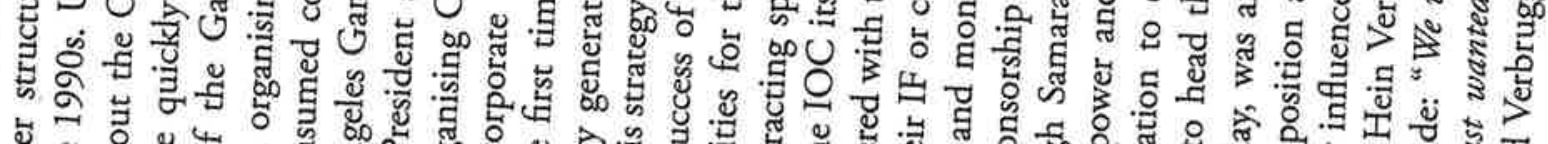

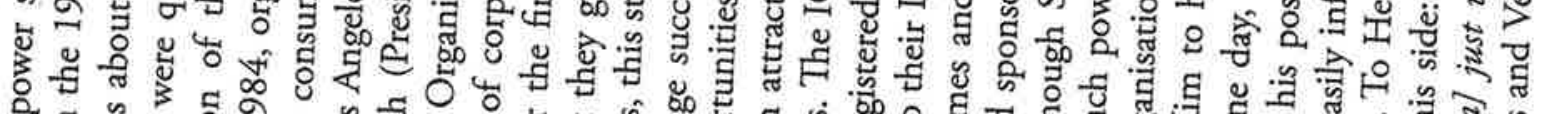

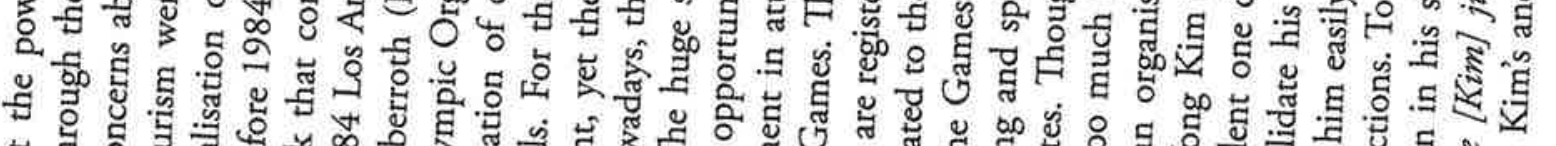
년 


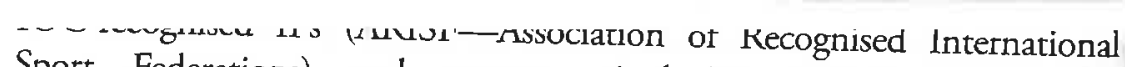
Sport Federations) and non-recognised IFs (AIMS-Alliance of Independent Recognised Members of Sport). All are members of SportAccord/GAISF. For a non-recognised IF to be recognised, the federation has to fulfil a number of criteria. Officially, the power to recognise an IF lies with the IOC. But as the federation first has to be a member of SportAccord/GAISF, the initial due diligence of verifying whether the IF is in compliance with IOC criteria falls to SportAccord/GAISF. This makes SportAccord/GAISF an important pillar of the IOC's recognition policy.

Over the years, IFs' efforts to become recognised posed a new but basic question: what is a sport? Under Verbruggen, SportAccord established a set of criteria to define what a sport is, a task that not even the IOC has ever undertaken. The full list of criteria is given below:

\section{List of criteria to define what is a sport}

- "The sport proposed should include an element of competition" (thus excluding e.g. yoga or Pilates).

" "The sport should not rely on any element of 'luck' specifically integrated into the sport" (such as e.g. horse racing).

and safety of its athot be judged to pose an undue risk to the health and safety of its athletes or participants" (such as e.g. base-jumping).

"The sport proposed should in no way be harmful to any living creature" (thus excluding e.g. fishing)

- The sport should not rely on equipment that is provided by a single supplier.

To be recognised by the IOC, IFs further need to prove the existence of an anti-doping policy compliant with the WADA Code, regularly stage World and Continental Championships, exhibit independent governance structures and "the sport it governs must be practised and organised in more than 50 countries worldwide". ${ }^{12}$ Even though IFs' recognition by the IOC is officially governed by the Olympic Charter (Rules 26 and 27), the actual evaluation is conducted by SportAccord/GAISE. The IOC, on the other hand, through its "Evaluation criteria for sports and disciplines", carries out an assessment of the contributions of Olympic IFs to the overall success of the Olympic Games (number of tickets sold, number of spectators, TV audience, etc.).

\section{SportAccord Convention}

In an environment where Samaranch was pursuing maximum control over the IFs and where GAISF President Kim sought to increase his own influence within the IOC, even if this meant thwarting suggestions and initiatives from IFs, new and innovative ideas were not a priority for GAISF. But this did not stop Verbruggen trying. As the IOC has to meet its four associations (i.e. ASOIF, AIOWF, ARISF, AIMS) at least once a year, he suggested organising an annual meeting over several days, bringing together all IFs. Thus the idea of the SportAccord Convention was born. Despite the successful first organisation of the SportAccord Convention in 2003, Kim continued to vehemently reject Verbruggen's initiative, almost causing him to give up. But with Kim's critic and Verture in 2004, the SportAccord Convention lost its harshest critic and Verbruggen became acting GAISF President in the same year. Emphasising the significance he assigned the SportAccord Convention, Verbruggen rapidly created a separate structure for the convention, owned $50 \%$ by GAISF, $30 \%$ by ASOIF and $20 \%$ by AIOWF. Since 2003, the SportAccord Convention has been an annual must for IFs. Over several days, it brings together about 2000 delegates, key decision-makers from sport governing bodies and the sports industry. It constitutes a platform for connecting, exchanging knowledge and parfrom the SportAccord the world of international sport. Today, revenues of GAISF income.

Hein Verbruggen stepped down as SportAccord President in 2013. Under Marius Vizer, Hein Verbruggen's successor at the head of SportAccord, the convention was rebranded as SportAccord Convention World Sport o Business Summit, thus accentuating Vizer's goal of furhis idea converging the world of sport and the world of business. However, his idea of organising joint World Championships every four years did not receive a favourable response from the IOC. Joint World Championships would strongly resemble the Olympic Games, with the not, could participate. of growing discrepancies between Vizer's objectives and the IOC, the
ond 
IOC did not hold an Executive Board meeting at the 2015 SportAccord Convention (Sochi). The subliminal conflict between the IOC and SportAccord exploded into a crisis when, in his opening speech and in the presence of IOC President Thomas Bach, Marius Vizer openly decried the IOC as being "expired, outdated, wrong, unfair and not at all transparent" ${ }^{13}$ Lacking the support of its members (20 SportAccord members cut ties or suspended membership in the aftermath of the 2015 Convention), Vizer ultimately stepped down from his position as SportAccord President in May 2015. Since this time, SportAccord's structure has been considerably reduced and the organisation of multi-sport games entirely.

\section{SportAccord: Organiser of Global Multi-Sport Games}

Supporting IFs to professionalise against a background of growing external expectation and financial pressures was Hein Verbruggen's first objective upon becoming GAISF President. Affording IFs, in particular small IFs, a certain visibility was another. The Olympic Games are one of the world's most important international sport events. At the time of writing this chapter, 35 of the 92 IFs that are full members of GAISF are on the Olympic programme (28 summer +7 winter). Recognising the potential of the 57 sports that are not, and perhaps never will be, on the Olympic programme, Verbruggen had the idea of grouping sports together to organise multi-sport games: "Amongst the 92 federations I had 14 or 15 martial arts. So I had Martial Arts Games. I had 4 or 5 federations that were mind games, bridge, chess and so on. So I created the Mind Games," (HV, November 2014). Thanks to Verbruggen's close relationship with Jacques Rogge (IOC President 2001-2013), the IOC supported the idea at the time. The economic model of the multi-sport games was similar to the Olympic Games: SportAccord owned the rights and appointed a local organiser who paid an organising fee (approximately CHF 3 million for the Martial Art Games and CHF 1.2 million for the Mind Games). SportAccord coordinated the development of the games together with its member IFs. Under the auspices of SportAccord, the SportAccord multi-sport games gave non-Olympic sports and disciplines worldwide exposure. Since 2010, two World Combat Games (2010 in Beijing 2013 in St. Petersburg) and four World Mind Games (2011-2014 in Beijing) have taken place. The first edition of the World Urban Games were scheduled for 2016 and the World Beach Games for 2017. However, not everyone welcomed this evolution: "Some people in the IOC wondered if it was the role of international sport federations to organise games," (HV, November 2014). The concept of SportAccord multi-sports games ground to a sudden halt with Marius Vizer's opening speech at the 2015 SportAccord Convention and his replacement as SportAccord President shortly after.

Verbruggen insisted that, under his presidency, SportAccord was not seeking to rival the Olympic Games, nor was it meant to be a counter-power to the IOC. He considered SportAccord primarily as a service provider to the IFs and the multi-sport games as a means of affording visibility to IFs that will perhaps never be included on the Olympic Programme. While his goal for SportAccord was to be financially independent of the IOC through the organisation of the SportAccord Convention and the multi-sport games, he recognised the need to work closely with the IOC for the benefit of the federations: "If you want to be a service operator to the federations, if you want to do something for them, you can't do it without the IOC, without a close cooperation between SportAccord and the IOC," (HV, May 2015). The immediate dropping of multi-sport games and other services (except anti-doping) and the return to its former acronym (GAISF) in 2017 under the new president demonstrate the current priorities of GAISF: maximum alignment with IOC requirements and minimum conflict, even if this means diminishing services to IFs.

\section{Allegations Against Hein Verbruggen}

While his time as UCI President passed generally uncontested and was rather evaluated in relation to the UCI's growing prosperity and structure, rumours and allegations came to the surface after Hein Verbruggen relinquished the UCI presidency in 2005. In 2008, a BBC investigation into UCI finances pointed a finger at payments made 
to the UCI nearly two decades earlier. The investigation focused on payments of USD 3 million to the UCI in the 1990s by a Japanese cycling event organiser. These payments coincided with the admission of the keirin into the Olympic programme. Keirin racing is one of the most popular disciplines for betting in Japan, "commanding tens of millions of dollars in gambling revenue every year". ${ }^{14}$ The disclosure of the payment fed rumours that keirin racing had bought its way into the Olympic Games and spawned allegations against the UCI for having accepted money in exchange for their support. Voted onto the 2000 Olympic 2000 Olympic Games. However, although rumours persisted for some Verbruggen, "the whole thing definitive proof of bribery. According to $U C I$ to arrange a deal thing was an idea of the IOC, who suggested the support UCI projects," (HV the keirin organiser, including a payment to "HV, March 2015).

After the keirin accusations, other allegations against Hein Verbruggen followed. In 2010, Floyd Landis claimed that cycling's governing body, and Hein Verbruggen and his successor Pat McQuaid respectively, had helped cover up a positive test by Lance Armstrong at the 2001 Tour de Suisse. The UCI brought a case against Landis who was found guilty of defamation by a Swiss court in 2012. And in 2011, both Hein Verbruggen and Pat McQuaid launched suits and in Paul Kimmage, a journalist and former rider, for defamation. The Court of Arbitration for Sport (CAS) gave its verdict in Mation. The ruling that Kimmage should pay CHF gave its verdict in May 2016, 12,000 in defamation damages ingly tolerated doping claiming that the latter "knowingly tolerated doping, concealed test results, is dishonest, does not behave responsibly, did not apply the same rules to everyone, did not pursue Lance Armstrong after he had been provided with a backdated certificate". ${ }^{15}$

Finally, the Cycling Independent Reform Commission (CIRC) report, published in March 2015 after a year-long investigation by an independent UCI Commission, cleared Pat McQuaid and Hein ods and accused outright corruption, but queried their governance methods and accused them of preferential treatment in specific cases. The ner without atates that Verbruggen ran the UCI "in an autocratic manner without appropriate checks and balances" ${ }^{16}$ Verbruggen undeniably governed the UCI with a strong executive power, himself overseeing internal, external and political issues and taking decisions "almost unchallenged" ${ }^{17}$ And he knew how to deploy his charm and use arguments to get people to act as he desired.

All these allegations underline the picture of Hein Verbruggen as a highly controversial figure. A lot of people who worked with him describe him as a charismatic, professional and tireless visionary who transformed the UCI, international cycling and sport in general: "Not many had the capacities of Hein Verbruggen to manage politics and business. He has an exceptional capacity to approach people and always find support" (former UCI employee, March 2015). Meanwhile, his opponents, including former cyclists and leading administrators in cycling (e.g. former UCI President Brian Cookson) and anti-doping (e.g. Richard Pound), criticised him repeatedly for his management style and alleged wrongdoings related to doping practices in cycling. This chapter has no intention of taking a position regarding the above allegations. Meanwhile, with doping allegations being a dominant and recurring topic in the last years of Verbruggen's life, the following section suggests an alternative view of doping based on the general perception and evolution of, and motives for, the fight against doping in sport. While the issues of the perception and evolution of the fight against doping are perhaps less publicly discussed, they strongly influence the current discourse on doping in cycling.

\section{An Alternative Perspective on Doping}

At the beginning of the twentieth century, the use of performanceenhancing drugs was more often considered a scientific miracle than an immoral, fraudulent or even health-threatening practice. It was only in the 1960s that a number of interrelated rumours and events began to change the perception of doping. A first rumour theorised that, during World War II, German soldiers were given steroids to create "hyper-masculinised, ultra-aggressive combat soldiers" (Beamish and Ritchie 2005). The second rumour was that athletes from communist countries had been consciously given steroids during the Cold War to 
boost performance in international sporting competitions and hence symbolically emphasise the power of the Eastern Bloc. The spectacular success of Eastern Bloc athletes together with a growing awareness of the health risks of using performance-enhancing drugs led to a change in the perception of doping. And with the death of Tom Simpson on Mont Ventoux in front of spectators and the TV audience, doping suddenly also had a face in cycling. Simpson died on 13 July 1967 from a combination of amphetamines (found in his jersey pocket), immense physical effort and heat. He has since become the emblematic figure of doping in cycling.

In the following years, doping bans were, above all, dominated by considerations about the riders' health. However, it wasn't until the 1990s with the rise of EPO and the Festina Affair that doping was considered morally unacceptable. While for decades conventional doping and its relatively predictable impact on performance seemed to be widely accepted among cyclists, the emergence of EPO unhinged the entire system. The performance increase through EPO was without precedent. Cyclists were alarmed as an equality of opportunity was no longer a question of chemical substances but of sophisticated, expensive medical procedures. In 1995, the UCI, under the presidency of Hein Verbruggen, commissioned a Lausanne-based laboratory to develop a procedure to detect EPO. But even this could not prevent the negative effects that the Festina Affair would have on the perception of cycling. The image of a sport engrained with doping persists to this day as much as the question of who is to blame.

As described above, the perception of doping has changed over the decades: from first being considered as a scientific achievement, then as a health-threatening product and finally as a morally illicit practice. Today, and more than in any other sport, the fight against doping in cycling seems to be exploited not only for moral arguments but also as a political tool under the guise of which individuals or groups of individuals pursue personal interests. With the general commercialisation of sport since the 1980s (Robinson 2003), there is more than just the practice of sport and the athletes themselves at stake. As the market value of sport has grown, so have the interests and investments of various actors including the media, sponsors and sport officials. In this context, doping represents an economic threat to sports in general and a detriment to the image of international sport federations in particular. Perhaps the important question is not "Whose fault is doping in cycling?" but "What dimensions other than moral principles should/could be taken into consideration in the fight against doping?" How about actors' economic motives (e.g. threat of losing sponsorship money because of doping scandals) and key individuals' political objectives (e.g. election campaigns in which the fight against doping sells well)? To this we can also add Aubel's (2013) sociological perspective, which focuses on cyclists' working environments (e.g. team structure, functional and economic model, physical preparation conditions and the employment framework offered to riders) and the question of elements that trigger doping practices and how the working environment should be modelled to prevent them.

A recent paper by Kayser and Tolleneer (2017) in the Journal of Medical Ethics discusses yet another interesting perspective. It picks up on the debate of two diametrically opposed discourses on ethics and doping. The first discourse "defends strict probibition enforced by surveillance and punitive repression" (p. 1), but is practically impossible to meet in terms of technology and surveillance; the second "finds anti-doping illogical and calls for the liberalisation of doping" (p. 1), but is likely to encourage excessive drug use by some athletes. Thus considering both discourses as non-realisable idealistic goals and raising the question of the possible aggravating effects of anti-doping policies, the authors adopt a systemic analysis to debate ethical aspects of relaxed anti-doping rules accompanied by harm-reduction measures. Kayser and Tolleneer acknowledge the incompleteness of their analysis (e.g. not taking athletes' decision-making capacities into account). However, their critical questions on the ethics of doping, situated at the interface of two extreme discourses, put forward the experimental dimension of their idea, rather than moralising a topic with an immensely complex and ambivalent past (scientific miracle, superhuman strength, humans as war machines) and the current problem of assessing often intangible parameters including "limits to testing technology and surveillance density" (p. 1). 


\section{Conclusion}

Hein Verbruggen undeniably divides opinions; he has as many supporters as opponents. Verbruggen has been celebrated as the person who made the UCI a successful, professional IF. Yet he has been attacked with serious allegations regarding his leadership style and approach to the fight against doping. The aim of this chapter is not to provide a complete picture of Hein Verbruggen as a person or comment on the different allegations, but rather to identify his impact on the organisational and functional structure of sport organisations during his time at the UCI and SportAccord/GAISF as well as his ability to implement corporate principles in sport organisations and to explore new ideas. His legacy is twofold: with regard to his time as UCI President, Verbruggen professionalised the administrative structure. He also triggered globalisation and the worldwide marketing of cycling by concentrating regulatory power in the UCI. "He came from business and it is his achievement that cycling professionalised" (former UCI employee, March 2015). Hein Verbruggen had a vision and his pragmatic, charismatic management became the guarantor of this vision. At the same time, critics reproach him for a failure to effectively combat cycling's internal ethical problems, such as widespread, organised doping practices and the associated dangers (athletes' health, fair-play, sporting ethics, etc.), in order to favour the sporting spectacle and financial profits and to create mythical champions such as Lance Armstrong. The image of Hein Verbruggen as a powerful, almost invincible president evokes other strong leaders from the same period such as Primo Nebiolo (International Association of Athletics Federations-IAAF President from 1981 until his death in 1999), Ruben Acosta (Fédération Internationale de Volleyball-FIVB President from 1984 to 2008) or Sepp Blatter (FIFA President from 1998 to 2015). These federations (UCI, IAAF, FIVB, FIFA) have in common that they were all coordinated by strong executive presidents who were committed to capitalising on sporting events, hence laying the foundation for the commercialisation of their federations. Hein Verbruggen was a guiding hand as President of the UCI and SportAccord/GAISF, surrounded by capable helpers thanks to his "fine sense for people, their motivation and their competencies" (former UCI staff member, 2005). Many who worked closely with him over the years described him as a tirelessly dedicated visionary, a good listener, always available, a perfectionist. His opponents accuse him of corruption and autocratic management. Hein Verbruggen died on 14 June 2017 at the age of 75.

\section{Notes}

1. Jean-Marie Leblanc, former Tour de France Director, about Hein Verbruggen in 2005. Source: "Le president", a book offered to Hein Verbruggen by the UCI at the end of his presidency in 2005.

2. Source: http://www.theguardian.com/sport/2012/oct/24/fiorenzo-magni.

3. Source: 1964 Olympic Charter Eligibility Rules of the IOC.

4. Source: Minutes of the 63rd meeting of the IOC.

5. Dreyfus affair: in 1894, French artillery officer Alfred Dreyfus was accused of revealing French military secrets to the German Embassy in Paris. Two years later, investigations by the counter-espionage service found evidence of Dreyfus' innocence. However, instead of admitting a judicial error, the army used falsified documents to accuse Dreyfus of additional charges. Under the pressure of activists (e.g. Émile Zola), the affair became a political and judicial scandal, dividing French society into supporters of Dreyfus and those who condemned him. Accusations against Dreyfus were finally found to be baseless and he was exonerated in 1906.

6. Source: http://lifestyle.boursorama.com/article/le-tour-de-france-en-dixchiffres-insolites_a828/1.

7. Source: www.atpworldtour.com/en/media/rankings-and-stats.

8. PGA: Professional Golfers' Association.

9. Source: http://www.cbssports.com/golf/news/2015-pga-championshipprize-money-every-golfers-payout-from-10m-pool/.

10. Source: http://www.cyclingnews.com/features/opinion-the-uci-worldtouris-a-failing-brand.

11. Source: Official Report of the Games of the XXIIIrd Olympiad Los Angeles, 1984.

12. Source: http://www.arisf.org/14-uncategorised/30-ioc-recognition.

13. Source: http://playthegame.org/news/news-articles/2015/0044_sportaccord-president-vizer-steps-down-after-row-with-ioc/. 
14. Source: http://www.playthegame.org/news/news-articles/2008/cyclingevent-alleged-to-have-bought-olympic-acceptance-from-uci/.

15. Source: http://www.insidethegames.biz/index.php/articles/1037889/ former-uci-president-verbruggen-wins-defamation-case-against-journalist-kimmage-in-swiss-courts.

16. Source: CIRCReport2015_Neutral.pdf, p. 8.

17. Idem.

\section{Bibliography}

\section{Literature}

Amis, John, Trevor Slack, and Christopher R. Hinings. 2004. Strategic Change and the Role of Interests, Power, and Organizational Capacity. Journal of Sport Management 18 (2): 158-198.

Aubel, Olivier. 2013. Trois propositions pour changer la culture du cycliste professionnel. Une politique rénovée de prévention du dopage. Schweizerische Zeitschrift Für Sportmedizin Und Sporttraumatologie 61 (3): 34-38.

Aubel, Olivier. 2015. Précarité économique et dérive des comportements: l'exemple du dopage dans le cyclisme. Le journal de l'école de Paris du management 111 (1): 38-44.

Barbusse, Béatrice. 2002. Sport et entreprise: des logiques convergentes? L'Année sociologique 52 (2): 391 -415.

Bayle, Emmanuel, Jean-Loup Chappelet, Aurélien François, and Lionel Maltèse. 2011. Sport et RSE. Vers un management responsable? Bruxelles: De Boeck Editions.

Beamish, Rob, and Ian Ritchie. 2005. The Spectre of Steroids: Nazi Propaganda, Cold War Anxiety and Patriarchal Paternalism. The International Journal of the History of Sport 22 (5): 777-795.

Chappelet, Jean-Loup. 1991. Le systeme olympique. Grenoble, France: Presses Universitaires de Grenoble.

Chappelet, Jean-Loup. 2008. International Olympic Committee and the Olympic System: The Governance of World Sport. Abingdon: Routledge.

Chappelet, Jean-Loup, and Brenda Kübler-Mabbott. 2008. International Olympic Committee and the Olympic System (IOC): The Governance of World Sport. London: Routledge. de Coubertin, Pierre. 1888. L'éducation en Angleterre. Paris: Collèges et Universités.

de Coubertin, Pierre. 1890. Universités transatlantiques. Paris: Hachette.

Grosset, Yoan, and Michaël Attali. 2009. The French Initiative Towards the Creation of an International Sports Movement 1908-1925: An Alternative to the International Olympic Committee. Journal of Sport History 36 (2): 245.

Hoye, Russell, and Sue Inglis. 2003. Governance of Nonprofit Leisure Organizations. Loisir et Société/Society and Leisure 26 (2): 369-387.

Kayser, Bengt, and Jan Tolleneer. 2017. Ethics of a Relaxed Antidoping Rule Accompanied by Harm-Reduction Measures. Journal of Medical Ethics 43 (5): 282-286.

Robinson, Leigh. 2003. The Business of Sport. In Sport \& Society: A Student Introduction, ed. B. Houlihan, 165-183. London: Sage. 